\title{
The Translation of Sex-related Content in Lady Chatterley's Lover in China
}

\author{
Kun Zhu \\ School of English Studies, Shanghai International Studies University, Shanghai, China
}

\begin{abstract}
This article discusses how sex-related content is rendered in two Chinese translations of D. H. Lawrence's Lady Chatterley's Lover: Rao Shuyi (1936) and Zhao Susu (2004). It is found that Rao's translation features explicitness, flexibility and Europeanization, while Zhao's translation features conservativeness and domestication. And the observed features in the two translations regarding sex-related content are explained from perspectives of social and historical background, translation purpose and intended readership, and patronage.
\end{abstract}

Index Terms—Lady Chatterley's Lover, translation, sexuality

\section{INTRODUCTION}

D. H. Lawrence, a renowned English writer, lived in the Victorian period, which was the golden age in British history. As the first country to enter the industrial society, England then enjoyed an unprecedentedly prosperous economy. However, the Victorian period was also an era full of tragedies, as stated in the opening of Lady Chatterley's Lover "Ours is essentially a tragic age, so we refuse to take it tragically. The cataclysm has happened: we are among the ruins" (Lawrence, 1959, p. 37). Specifically speaking, most people in this period were inescapably controlled by machine; and the dominant social class was avariciously pursuing money and fame. Meanwhile, "from the highest class of society down to the lowest every one lives as under the eye of a hostile and dreaded censorship" (Mill, 2009, pp. 102-103). Lawrence believed that in order to liberate people from enslavement of machine and from restraints of censorship, a new social order should be established with basic human needs and human nature taken into account (Rao, 1986, p. 2). Under such circumstances, he created Lady Chatterley's Lover. The story is about the passionate, but unaccepted love between Lady Chatterley and her husband's gamekeeper, Oliver Mellors. By creating the work, Lawrence intended to awaken people to fight for self-existence, to get rid of the suppression imposed by modern civilization, and to establish harmony between male and female, between man and society.

Despite of its significance, Lady Chatterley's Lover met challenging obstacles in its early publication and circulation. At first, it was banned in England and America for its excessive sex-related content. Until 1932, an expurgated version of Lady Chatterley's Lover was published in England and America. Almost thirty years later, an unexpurgated version was published by Penguin Press in London to mark the $30^{\text {th }}$ anniversary of Lawrence's passing away in 1960. However, the publication incurred a lawsuit: London's chief prosecutor Jones accused the book of propagating sensualism and praising adultery. Fortunately, after six days of intense debate in court, Penguin Press won the case (Lu, 2004, pp. 3-5). The publication and circulation of Lady Chatterley's Lover in China didn't go swimmingly as well. It was introduced to China in 1930s, and many renowned Chinese scholars, such as Yu Dafu ${ }^{1}$ and Lin Yutang ${ }^{2}$, wrote articles on it. But it was banned due to the Cultural Revolution and it was not until the late 1980s that Lady Chatterley's Lover came into circulation again (Cui, 2014, p. 22).

The difficulties of publication and circulation confronted by Lady Chatterley's Lover were largely caused by its excessive sex-related content, which was usually considered as obscene or even immoral. So this article intends to investigate how sex-related content is rendered in two widely acclaimed Chinese translations of Lady Chatterley's Lover, to summarize features in the two translations regarding sex-related content, and to explore underlying reasons behind the observed features.

\section{Two Chinese Translations AND Their Translators}

Since 1930s, Lady Chatterley's Lover was translated into Chinese by some Chinese translators, including Lin Yutang,

\footnotetext{
${ }^{1}$ Yu Dafu, a modern Chinese writer and revolutionary martyr, was one of the initiators of the new literary group called "the Creation Society". His literary masterpieces include Sink Down, Spring Fever, and Sweet-scented Osmanthus in Belated Bloom. In addition to literary creation, he also actively participated in various anti-imperialist and anti-Japanese activities. In his article "On reading Lawrence's novel Lady Chatterley's Lover", Yu Dafu (1934) not only investigated the characteristics of the novel, but also analyzed its structure and the thought of Lawrence reflected in it (pp. 33-37).

${ }^{2}$ Lin Yutang was a renowned modern Chinese writer, translator, linguist. He was nominated for the Nobel prize in literature twice respectively in 1940 and 1950. His literary works include Moment in Peking, My Country and My People, the Importance of Living. Lin Yutang (1935) wrote in his article "On Lawrence" that the sex scenes in Lawrence's works integrated soul and flesh and reproduced the inner world of characters and the symbolic relationship between individuals and society, which was of profound connotation (pp. 33-37).
} 
Wang Kongxi, and Qian Shi (Sun, 2008, pp. 120-123). But the full text of Lady Chatterley's Lover was first translated into Chinese by Rao Shuyi in 1936. And it was not until 1990s that other translation versions began to emerge. Now, there are over a dozen of translation versions in China. This article selects two widely acclaimed versions as the research objects and an introduction to the two versions and their translators is presented below.

The first version is Rao Shuyi's translation published in 1936. When reading translation excerpts of Lady Chatterley's Lover in newspapers, Rao found quite a few errors and omissions which he believed obstructed readers from appreciating authenticity of the original work. So he decided to sort out his previous translation excerpts of Lady Chatterley's Lover and to complete the unfinished parts of it. He used the unexpurgated English version published in France as the source text and also referred to French version by Roger Cornaz, Lawrence's designated translator of French version. As for his own translation, he commented that although his translation was not worthy of acclaim, it remained as faithful as possible to the original work (Rao, 1986, p. 4). His translation was not republished until 1986 when Hunan People's Press decided to republish it.

The second version is Zhao Susu's translation published by People's Literature Publishing House in 2004. In 2001, People's Literature Publishing House decided to republish Lady Chatterley's Lover and invited Zhao to translate it. Although Zhao had successfully translated more than twenty English works into Chinese before having been commissioned to translate Lady Chatterley's Lover, it was still never easy for him to translate this work well. Specifically speaking, Lawrence was used to wording and phrasing exquisitely and citing copiously from classics in his works, and he did so in creating Lady Chatterley's Lover. Zhao was able to find most sources of Lawrence's citations and translated them appropriately, but to exactly reproduce the language style of the original work was almost unattainable given the time limit of the translation task. So some adjustments had to be made. For example, the Derbyshire dialect that Mellors spoke was difficult to be rendered into Chinese, so Zhao replaced it with Chinese local dialect. Besides, to get the translation approved by the censorship department, Zhao chose to downplay and expurgate some sex-related content in his translation, though he thought Lady Chatterley's Lover was not obscene but even philosophically enlightening (Zhao, 2004, p. 390). However, in general, he kept the adjustments from interfering with his presentation of the overall integrity of the original work.

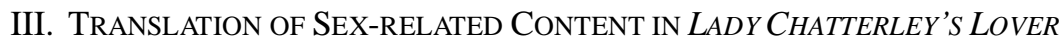

In Lady Chatterley's Lover, a large amount of sex-related content has been accused of propagating sensualism and praising adultery. However, presenting much sex-related content in this novel, Lawrence didn't intend to suggest that all women should go running after gamekeepers for lovers or to suggest that they should go running after anybody. He stated his intention as "I want men and women to be able to think sex, fully, completely, honestly, and cleanly. Even if we can't act sexually to our complete satisfaction, let us at least think sexually, complete and clean" (Lawrence, $2006, \mathrm{p}$. 308). This section investigates how sex-related content in Lady Chatterley's Lover is treated in Rao's translation and in Zhao's translation respectively from three aspects.

\section{A. Sexually Sensitive Words}

The first component of sex-related content in Lady Chatterley's Lover is sexually sensitive words, which can be subdivided into three groups. The first group is words related to sexual organs, such as cock, penis, ball, cunt and womb; the second group is words related to body parts, such as breast, belly, navel and buttock; the third group is words related to sexual intercourse, such as fuck, erect, come off, and sexual orgasm. One word from each group is selected and then a comparison between Rao's translation and Zhao's translation regarding the selected word is conducted.

\section{Words Related to Sexual Organs}

In this group of words, "penis" is chosen as the research object. In the source text of Lady Chatterley's Lover, "penis" appears twenty-one times to refer to a male's body part that is used for urinating and sex. In Rao's translation, he translated “penis” into “阴茎”, fifteen times, “阳具”, four times, and “生殖器”, twice. In Zhao's translation, he translated “penis” into “阳具” seven times, “枪” twice, “命根子” once, “那话儿” once, and “它” once; and he omitted "penis" in his translation nine times. So it can be found that Zhao tended to use euphemism or omission to translate "penis", while Rao was more direct in this regard. Two examples are provided below to better present how "penis" is rendered in Chinese by Rao and by Zhao respectively.

Example 1: She saw the image of him, naked white with tanned face and hands, looking down and addressing his erect penis. (Lawrence, 1959, p. 332)

Rao's translation: 她的心里看见他, 赤裸裸的, 白晳晳的, 只有脸孔和两手是赤色的。他闭着眼睛, 对她挺起

\footnotetext{
3 “阴茎” is formal expression of “penis” in Chinese and can be used as a medical term.

4 “阳具” is usually used in literary works to refer to "penis" and can be sexually arousing.

5 “生殖器” is an equivalent of "reproductive organ” in English.

6 “枪” is an euphemism for "penis" in Chinese.

7 “命根子” is a nickname for "penis" in Chinese.

8 “那话儿” is an euphemism for “penis" in Chinese.

9 “它” refers to “penis” based on the context in the translation.
} 
的阴茎说着话。(Rao, 1986, p. 385)

Zhao's translation: 她眼前浮现出他的样子, 赤裸洁白, 脸和手是晒黑的, 他望着自己挺立的那话儿, 对它说 着话。(Zhao, 2004, p. 332)

Example 2: She felt his penis risen against her with silent amazing force and assertion. (Lawrence, 1959, p. 229)

Rao's translation: 她觉得他的阴茎带着一种静默的、令人惊奇的力量与果断, 向她坚举着。(Rao, 1984, pp. 249-250)

Zhao’s translation: 她觉得他正以令人惊奇的力量与坚决, 无声地向她靠近。(Zhao, 2004, p. 216)

In the first example, while "penis" was explicitly translated into “阴茎” by Rao, Zhao chose to deal with it in an implicit and less sexual manner and translated it into “那话儿”. In the second example, Rao rendered “penis" in the same way, but Zhao omitted it in his translation. So judging from these two examples and the statistics presented above, it can be concluded that while Zhao tended to render "penis" euphemistically, Rao was more direct in his translation.

\section{Words Related to Body Parts}

Regarding words related to body parts, "buttock" is selected as the research object. In the source text of Lady Chatterley's Lover, "buttock" appears sixteen times to describe the two rounded freshly parts at the top of a person's legs. In Rao's translation, he translated “buttock” into “臀部” five times, “屁股” twice, “两股” twice, “慰” twice, “后 臀” once, “慰尖” once, “两臀” once, “慰上” once, and omitted one “buttock”. In Zhao's translation, he translated “buttock” into “慰部” seven times, “屁股” six times, “后慰” once, “慰” once, “两股” once. So Rao used eight different expressions to render "buttock" in Chinese, while Zhao used only five. And one example is offered below.

Example 3: And the longish slope of her haunches and her buttocks had lost its gleam and its sense of richness. (Lawrence, 1959, p. 111)

Rao’s translation：慰部两旁和臀尖的下倾，已失掉了它的光辉和富丽的神态了。(Rao, 1986, p. 96)

Zhao's translation: 倾斜的臀部已失去了往日的滑淢丰舆感。(Zhao, 2004, p. 84)

In this example, "buttocks" and "haunches" are synonyms. While Zhao translated both of them into “筒部”, Rao translated “haunches” and “buttocks” into “矦部” and “臀尖” respectively, which reflects the diversity of Rao's translation. Besides, “筲尖” is more vivid than “算部” in Chinese. Judging from this example and the statistics presented above, it can be concluded that Rao's translation for this word was relatively diverse than Zhao's.

\section{Words Related to Sexual Intercourse}

As for words related to sexual intercourse, "fuck" is the research object. In the source text of Lady Chatterley's Lover, “fuck” appears twenty-four times. In Rao's translation, he translated “fuck” into “性交” seventeen times, “荷合” once, “交合” once, “怜爱” once, “进入” once, “床第间事” once, “相交” once, and omitted one. In Zhao's translation, he translated “fuck” into “做爱” sixteen times, “欲” once, “荷合” once, “干” once, “床第之事” once, “睡觉” once, and omitted three. Regarding the most frequently used translation of "fuck”, “性交” in Rao's translation is usually used in formal text while Zhao's translation “做爱” is usually used in informal text. In terms of language diversity, there is little difference between Rao's translation and Zhao's translation, but Zhao deleted three "fuck" in his translation for the context of them in the source text contains excessive sex-related content and thus he chose to abridge the entire context.

\section{B. Love Making Scenes between Lady Chatterley and Mellors}

In Lady Chatterley's Lover, description of sexual intercourse can't be ignored. From a social point of view, by depicting sexual intercourse vividly, Lawrence intended to demonstrate the difficulty and the necessity for men and women to establish an integrated and sound partnership both physically and spiritually (Zhao, 2004, p. 387). From a narrative point of view, sexual intercourse is presented with increasing explicitness and meticulousness, which reflects the slowly growing intimacy between Lady Chatterley and Mellors. At first, they restrained themselves from starting a romance for both of them were disappointed by their past romantic experience. So it is depicted in the first love making scene between them that "she lay still, in a kind of sleep, always in a kind of sleep. The activity, the orgasm was his, all his; she could strive for herself no more" (Lawrence, 1959, p. 164). Then, the relation between them heated up and gradually grew into a romantic one. Accordingly, the latter loving making scenes were more vibrant and exhilarating as depicted as follows: "sharp soft waves of unspeakable pleasure washed over her as he entered her, and started the curious molten thrilling that spread and spread till she was carried away with the last, blind flush of extremity" (Lawrence, 1959, p. 272). Regarding the two translators' translation of love making scenes, two excerpts are selected for analysis.

Excerpt 1: She lay still, in a kind of sleep, always in a kind of sleep. The activity, the orgasm was his, all his; she could strive for herself no more. Even the tightness of his arms round her, even the intense movement of his body, and the springing seed in her, was kind of sleep, from which she did not begin to rouse till he had finished and lay softly panting against her breast. (Lawrence, 1959, p. 164)

Rao's translation: 在一种沉睡的状态中, 老是在一种沉睡的状态中, 她静默地躺着。所有的动作, 所有的性兴 奋, 都是他的, 她再也无能为力了。甚至他的两臂搂着她那么紧, 甚至他身体的激烈的动作, 以及他的精液在 她里面的播射, 这一切都在一种沉睡的状态中过去, 直至他完毕后, 在她的胸膛上轻轻地喘息着时, 她才开始 醒转过来。(Rao, 1986, p. 165) 
Zhao's translation: 她静静地躺着, 似睡非睡, 总是似睡非睡。所有的动作, 所有的性兴奋, 都是他的, 全都 是他的; 她无法再努力了。即使他两臂紧搂着她, 即使他的身体激烈运动, 把精液射在她身体里时, 她还是那 样睡着，直到他完了事，在她胸前轻轻喘息，她才开始醒转过来。(Zhao, 2004, p. 142)

This excerpt depicts the first love making scene between Lady Chatterley and Mellors. During the whole process, Mellors took the initiative and Lady Chatterley lay still rather than responded to Mellors, which implies her struggle between moral restraint and sexual desire. Regarding the translation of the excerpt's first sentence, while Zhao followed the original order of words, Rao adjusted the order of words in his translation, which embodies Rao's relative flexibility in his translation. Besides, Rao's translation of this excerpt is Europeanized, which features "translationese", such as his translation “他的精液在她里面的播射, 这一切都在一种沉睡的状态中过去, 直至他完毕后”; however, Zhao adopted domestication translation, which is in compliance with contemporary Chinese readers' reading habits.

Excerpt 2: She turned round and climbed into his lap, clinging to him. "Kiss me!" she whispered.

And she knew the thought of their separation was latent in both their minds, and at last she was sad.

She sat on his thighs, her head against his breast, and her ivory-gleaming legs loosely apart, the fire glowing unequally upon them. Sitting with his head dropped, he looked at the folds of her body in the fire-glow, and at the fleece of soft brown hair that hung down to a point between her open thighs. He reached to the table behind, and took up a bunch of flowers, still so wet that drops of rain fell on the floor. (Lawrence, 1959, p. 285)

Rao's translation: 她回转身去, 爬在他的膝上, 紧依着他。

“亲吻我罢! ”她细声说。

她明白了他俩的心里都带着离情别意, 最后她觉得悲伤起来了。

她坐在他的大腿上, 她的头依着他的胸膛。她象牙似的光耀的两腿, 懒慵慵地分开着; 炉里的火光参差地照 着他们。令他俯着头, 在那火光里, 望着她的肉体的折纹, 望着她开着的两腿间那褐色的阴毛。他伸手在后面 桌上把刚才她采来的花拿了, 这花还是湿的, 几滴雨水滴在她的身上。(Rao, 1986, p. 324)

Zhao's translation: 她回转身, 爬到他腿上, 紧依着他。“吻我! ”她悄声说。

她知道他俩的心里都蔵着离情别意, 她终于覚得悲伤起来。

...... (Zhao, 2004, p. 278)

This excerpt describes a scene that after having played in the rain, Lady Chatterley and Mellors came back to the cabin and decorated each other's naked bodies with flowers they gathered in the forest, which manifests the intimacy between them. Meanwhile, this excerpt also reflects Lawrence's philosophy and one of the themes of the novel: people should return to nature and learn to live in harmony with nature. Rao remained faithful to the content of the original excerpt in his translation, but Zhao chose to abridge most part of this excerpt due to its abundant sex-related content. In addition to this abridgment, Zhao also abridged quite a few love making scenes in other parts of his translation. Such a choice, to some extent, compromises the artistic value of the novel and fails to present a complete picture of the original novel to its readers.

\section{Lovely Chat between Lady Chatterley and Mellors}

Dialogue is an important part of language description in novels. On the one hand, successful dialogue description can express characters' thoughts and feelings and reflect their psychological activities; on the other hand, it can also predict and promote the development of plots, and explain the context of plots. In Lady Chatterley's Lover, lovely chat between Lady Chatterley and Mellors serves such functions. In regard to how lovely chat between them is rendered into Chinese by the two translators, the following excerpt is presented.

Excerpt 3: "Ma lass!" he murmured. "Ma little lass! Dunna let's fight! Dunna let's niver fight! I love thee an' th' touch on thee. Dunna argue wi' me! Dunna! Dunna! Dunna! Let's be together."

She lifted her face and looked at him.

"Don't be upset," she said steadily. "It's no good being upset. Do you really want to be together with me?"

She looked with wide, steady eyes into his face. He stopped, and went suddenly still, turning his face aside. All his body went perfectly still, but did not withdraw.

Then he lifted his head and looked into her eyes, with his odd, faintly mocking grin, saying: "Ay-ay! Let's be together on oath."

"But really?" she said, her eyes filling with tears.

“Ay really! Heart an' belly an' cock". (Lawrence, 1959, pp. 267-268)

This lovely chat occurred when Lady Chatterley and Mellors disagreeably argued over the essence of life, love and sex, and Mellors comforted Lady Chatterley and promised to be together with her who was then moved into tears. In this chat, they clarified their relationship and planned their future, which is important for the development of the story. The two translators' translations of this chat are as follows.

Rao's translation: “我的小人儿! ”他用土话喃喃地说: “我的小人儿! 我们不斗气罢! 让我们永不要斗气罢! 我 爱您, 我爱抚摸您。别和我争执! 不! 不! 不! 让我们和好在一块儿罢。”

她抬头望着他。

“不要烦闪。”她镇静地说: “烦问是没有用的。你真是想和我和好在一块儿么?” 
她的宽大而镇静的眼睛望着他的脸。他停住手，突然地静默起来，脸回避着。但是他的身体并没有避开。 然后他回过头来, 向她眼里望着, 脸上带着他那古怪的讽刺的苦笑说: “是的！让我们和好在一块儿, 誓不相 分!”

“是真的么? ”她说, 两眼充满着眼泪。

“是的, 真的！心和腹和阳具都和您在一块儿”。(Rao, 1986, p. 301)

Zhao's translation: “心肝儿! ”他喃哺地说, “俺的小心肝儿! 咱别斗气了! 咱们再也别斗气了! 俺爱你, 俺要 好好缠着你。别和俺吵了！别价！别价！别价！咱们在一块儿吧。”

她扬起脸, 望着他。

“别生气，”她镇定地说。“生气不好。你真的想和我在一块儿吗?”

她那大睁着的眼晴目不转晴地注视着他的面孔。他停止了抚摸, 突然一动不动了, 他转过脸去。他的身体一 动不动, 但是并没有躲开。

然后他抬起头来, 看着她的眼睛, 脸上淡淡地挂着那种古怪的嘲讽笑容, 说: “真想! 在一块儿, 誓不分离!” “真的吗? ”她说, 眼睛里含满了泪水。

“真的！不信你摸摸俺心窝子，摸摸俺肚皮子，摸摸俺......”。(Zhao, 2004, p. 260)

After meticulous comparative analysis of the two translations, several apparent differences can be found. First, compared to Zhao, Rao simplified the language and information of the chat in his translation, which reflects his flexibility in translation. For example, as for the sentence "All his body went perfectly still, but did not withdraw", Rao translated it into “但是他的身体并没有避开”, while Zhao translated it into “他的身体一动不动，但是并没有躲开”. Another example is “Heart an' belly an' cock”. Rao's translation is “心和腹和阳具都和您在一块儿”, while Zhao's translation is “不信你摸摸俺心窝子, 摸摸俺肚皮子, 摸摸俺......”. Another difference can be found in their translations of this sentence: Zhao deleted "cock" in his translation, while Rao translated it directly into “阳具”, which again demonstrates Rao's explicitness in his translation regarding sex-related content. Besides, Zhao used words of Chinese northern dialect in his translation, such as “俺” and “别价”, while Rao used Europeanized expressions in his translation, such as “我爱抚摸您” and “心和腹和阳具都和您在一块儿”.

\section{Features in the Two Translations and the Reasons Behind}

\section{A. Summary of Features in the Two Translations}

After comparative analysis of the two translations above, features in the two translations regarding sex-related content can be summarized as below. Rao's translation features explicitness, flexibility, and Europeanization, while Zhao's translation features conservativeness and domestication. As for the underlying reasons behind these features, this article intends to explore from three perspectives, namely social and historical background, translation purpose and intended readership, and patronage.

\section{B. Influence of Social and Historical Background}

Translation doesn't occur in a vacuum but in a social and historical context. The two translations of Lady Chatterley's Lover happened in two different periods with an almost seventy-year time span, during which tremendous transformation has taken place in China. Thus, their features should be first analyzed from social and historical perspective. Rao translated Lady Chatterley's Lover in 1930s when the impact of the New Cultural Movement was still profound. Free-minded intellectuals propagated modern western ideology, culture, politics and technology to counter against traditional Confucian doctrines, which created a relatively free, open and tolerant social environment. It can be proved by the frequent publication of translations and studies of Lady Chatterley's Lover in well-circulated newspapers. So Rao's explicitness in his translation of sex-related content was acceptable to the academic community and the general public as well. Besides, although publication censorship was established in the Republic of China era, only political publications would be censored rigorously while cultural and educational publications enjoyed a relatively loose censorship (Luo, 2015, p. 25), which created another prerequisite for Rao's explicitness in his translation.

Moreover, since translated literature is a system operating in the larger social, literary and historical systems of the target culture (Munday, 2012, p. 165), translated literature's position in the target culture also exerts influence on how literature is translated. Specifically speaking, when a "young" literature is being established, when a literature is "peripheral" or "weak" or when a literature is experiencing a critical turning point or in a vacuum, translated literature then occupies the primary position. Under such circumstances, translated literature tends to be less restrained by the language pattern in the target culture. In contrast, when translated literature occupies a secondary position, it usually preserves conventional forms and conforms to the literary norms in the target culture (Even-Zohar, 2004, pp. 193-194). Although the new-vernacular literature in China had been established since the May Fourth Movement, it was far from mature in 1930s, as a result of which translated literature still served as an important means for the academic community to learn from mature western literature. In addition, China was at the turning point of social transformation in 1930s, and accordingly Chinese literature was brewing reform. Two conditions combined led to translated literature's primary position in the target culture, which made it acceptable for Rao's translation of Lady Chatterley's Lover to 
contain a large number of Europeanized expressions. On the contrary, the time Zhao translated Lady Chatterley's Lover was 2004 when translated literature had already been pushed to the periphery in the Chinese literary polysystem, so it can be found that his translation of Lady Chatterley's Lover is more consistent with the target language convention.

\section{Influence of Translation Purpose and Intended Readership}

In literary translation, the purpose of translation directly affects the reproduction of the content and the style of the original texts. As mentioned in the previous section, the reason why Rao translated Lady Chatterley's Lover was to amend quite a few errors and omissions in its translations published in newspapers and to present readers with an opportunity to appreciate authenticity of the original work (Rao, 1986, p. 4). In a deep sense, Rao's translation aimed to break traditional moral values, criticize the suppression of human nature from society, advocate the beauty of life and the harmony between two genders, and propagate the concepts of democracy and freedom in China (Rao, 1986, p. 3). These two translation purposes together contributed to explicitness in his translation of Lady Chatterley's Lover. In addition to translation purpose, intended readership also plays a part in translation process; in other words, intended readers' aesthetic taste, reading attitude, educational level, and familiarity and receptivity to foreign languages, cultures and literature affect translators and their translations to some extent. Back then, the intended readers of Rao's translation were mainly free-minded intellectuals who were usually tolerant of sex-related content and favorably received Europeanized language. So it makes sense that Rao's translation features explicitness and Europeanization.

In contrast, the purpose of Zhao's translation was to increase readability and introduce the classic of world literature to Chinese readers from all walks of life. Accordingly, on the one hand, Zhao conformed to the language convention of Chinese and adopted domestication in his translation to cater for reading habits of his audience; on the other hand, Zhao expurgated plenty of sex-related content and instead focused more on the dissemination of Lawrence's social and ecological ideals.

\section{Influence of Patronage}

"Patronage is a potent force that can further or hinder the reading, writing, and rewriting of literature. It can be exerted by persons, a group of persons, a religious body, a political party, a social class, a royal court, publishers, and last but not least, the media" (Lefevere, 2010, p. 15). As his own patron, Rao published his translation of Lady Chatterley's Lover at his own expense, as a result of which he enjoyed a high degree of freedom in dealing with sex-related content. So in his translation of sex-related content, readers can find not only his explicitness and Europeanization as discussed above, but also his flexibility which is manifested by adjustments to sentence structures and diversity in wording. Oppositely, Zhao translated Lady Chatterley's Lover with the patronage of People's Literature Publishing House, which forced him to largely follow his patron's ideology in his translation. As pointed out by Sun Shunlin, the director of planning department of People's Literature Publishing House, Lady Chatterley's Lover is a work of art and the republication of it is not intended to cater for excessively sexual description in current literature (Wang, 2012, p. 27). Consequently, Zhao deleted plenty of sex-related content in his translation to fulfill the responsibility to his patron.

\section{CONCLUSION}

In order to awaken people to think sex, fully, completely, honestly, and cleanly, Lawrence presented a large quantity of sex-related content in Lady Chatterley's Lover. As a result, the publication and circulation of Lady Chatterley's Lover in China underwent twists and turns: it was introduced to China in 1930s, banned from 1950s to 1970s, lifted from the ban in 1980s, and vastly circulated since 1990s. Now, over a dozen of translation versions can be found in China, each of which has its own features in rendering sex-related content so as to ensure the translation's presence in the world, its reception and consumption in the form of a book. So are the two translations discussed in this article. This article has analyzed how the two translations rendered sex-related content from three aspects, namely, sexually sensitive words, love making scenes between Lady Chatterley and Mellors and lovely chat between them, and then found that Rao's translation features explicitness, flexibility and Europeanization, while Zhao's translation features conservativeness and domestication. Besides, this article has explained the observed features in the two translations from perspectives of social and historical background, translation purpose and intended readership, and patronage.

Given the article length's limit, this article has only discussed Rao's translation and Zhao's translation of Lady Chatterley's Lover. Since there are over a dozen of translation versions in China, further research should investigate how sex-related content is rendered in other Chinese versions, which may present a more complete picture of the translation and circulation of Lady Chatterley's Lover in China.

\section{REFERENCES}

[1] Cui, X. Y. (2014). The translation and circulation of Lady Chatterley's Lover in China. Language Planning, 8, $22-23$.

[2] Even-Zohar, I. (2004). The position of translated literature within the literary polysystem. In L. Venuti (Ed.), The translation studies reader. London and New York: Routledge, 192-197.

[3] Lawrence, D. H. (1959). Lady Chatterley's Lover. New York: Grove Press. 
[4] Lawrence, D. H. (1986). Lady Chatterley's Lover (S. Y. Rao, Trans.). Changsha: Hunan People's Press. (Original work published 1933)

[5] Lawrence, D. H. (2004). Lady Chatterley's Lover (S. S. Zhao, Trans.). Beijing: People's Literature Publishing House. (Original work published 1933)

[6] Lawrence, D. H. (2006). A propos of "Lady Chatterley’s Lover”. In M. Squires (Ed.), Lady Chatterley's Lover and a propos of "Lady Chatterley's Lover". Cambridge: Cambridge University Press, 303-336.

[7] Lefevere, A. (2010). Translation, rewriting, and the manipulation of literary fame. Shanghai: Shanghai Foreign Language Education Press.

[8] Lin, Y. T. (1935). On Lawrence. Renjianshi, 19, 33-37.

[9] Lu, J. D. (2004). Preface. In S. S. Zhao (Ed.), Lady Chatterley's Lover. Beijing: People's Literature Publishing House, 1-13.

[10] Luo, Q. (2015). The analysis on the publishing management system in the Republican period of China. Master's dissertation, Central China Normal University.

[11] Mill, J. S. (2009). On liberty. Auckland: Floating Press.

[12] Munday, J. (2012). Introducing translation studies: theories and applications. London and New York: Routledge.

[13] Rao, S. Y. (1986). Translator's preface. In S. Y. Rao (Ed.), Lady Chatterley's Lover. Changsha: Hunan People's Press, 1-5.

[14] Sun, J. C. (2008). Early translation and reception of Lady Chatterley's Lover in China. Journal of Sichuan International Studies University, 2, 119-124.

[15] Wang, Q. Q. (2012). The manipulation of patronage of translation practice-A comparison study on two Chinese versions of "Lady Chatterley's Lover". Journal of Anshun University, 14(2), 26-28.

[16] Yu, D. F. (1934). On reading Lawrence's novel Lady Chatterley's Lover. Renjianshi, 14, 33-37.

[17] Zhao, S. S. (2004). Translator's note. In S. S. Zhao (Ed.), Lady Chatterley's Lover. Beijing: People's Literature Publishing House, 384-391.

Kun Zhu was born in Hubei, China in 1992. He is currently a post-graduate student in English Language and Literature in Shanghai International Studies University. His research interest area is translation studies. 